\title{
Scanty Score
}

National Cancer Institute

\section{Source}

National Cancer Institute. Scanty Score. NCI Thesaurus. Code C88124.

A finding of 1-9 acid-fast bacilli per 100 immersion fields. 